\title{
Hsiu-Mei Huang (Taiwan) Applying Augmented Reality for Experiential Learning: A Case Study of E-Commerce Learning
}

\begin{abstract}
Summary: The great impacts of advancing technology, such as 3D virtual worlds, create new learning opportunities for learners. Educators and researchers have been exploring how to apply $3 D$ virtual technology to improve the virtual learning process and authentic activities. Augmented reality (AR) technology offers the opportunity for learners to interact in both the virtual and real world significantly. Augmented reality can be an attractive technology that allows learners to realize that virtual and real objects coexist at the same time. Therefore, AR technology allows educators to design courses utilizing simulation, visualization, and interaction with the virtual objects and real environments. For Dewey (1916), learning should be real and applicable to daily living. This study builds an e-commerce learning system based upon Kolb's experiential learning theory.
\end{abstract}

Keywords: Augmented reality (AR), Kolb's experiential learning cycle, E-commerce

Резюме (Хсиу-Мей Хуанг: Использование технологии дополненной реальности в основанном на опыте обучении: исследование на конкретном примере электронного коммерческого обучения): Речь идет об огромном влиянии передовых технологий, таких как, например, технология виртуальных 3D-миров, предлагающих обучающимся новые возможности обучения. Педагоги и исследователи обнаружили, как можно использовать виртуальные 3D-технологии для усовершенствования учебных процессов и аутентичных видов деятельности. Технология дополненной реальности (ДР) предлагает обучающимся возможности значительного взаимодействия как в виртуальном, так и реальном мире. Технология дополненной реальности может стать эффективной технологией, предоставляющей обучающимся возможность увидеть, что виртуальные и реальные объекты могут сосуществовать одновременно. В связи с этим технология ДР позволяет педагогам разрабатывать курсы, в которых можно использовать симуляцию, визуализацию и интеракцию с виртуальными объектами в реальной обстановке. Для Дьюи (1916) обучение должно было быть приближенным к реальности и связанно c повседневной жизнью. Данное исследование разрабатывает систему электронного коммерческого обучения на основе теории основанного на опыте обучения по Кольбу. Ключевые слова: технология дополненной реальности (ДР), Кольб, основанное на опыте обучение, цикл, электронная коммерция

Zusammenfassung (Hsiu-Mei Huang: Die Augmented-Reality-Anwendung im erfahrungsbasierten Lernen: eine Fallstudie zum E-Commerce Learning): Es geht um die großen Auswirkungen der fortschreitenden Technologie, wie zum Beispiel virtuelle 3D-Welten, neue Lernmöglichkeiten für die Lernenden. Pädagogen und Forscher haben herausgefunden, wie man virtuelle 3D-Technologie anwenden kann, um virtuelle Lernprozesse und authentische Aktivitäten zu verbessern. Die Technologie von Augmented Reality (AR) bietet die Möglichkeit für Lernende, sowohl in der virtuellen als auch in der realen Welt bedeutungsvoll zu interagieren. Augmented Reality kann eine attraktive Technologie sein, die es den Lernenden ermöglicht zu sehen, dass virtuelle und reale Objekte gleichzeitig koexistieren können. Daher erlaubt die AR-Technologie den Pädagogen, Kurse zu entwerfen, in denen Simulation, Visualisierung und Interaktion mit den virtuellen Objekten und realen Umgebungen genutzt werden können. Für Dewey (1916), sollte das Lernen wirklichkeitsnah und auf das tägliche Leben bezogen sein. Diese Studie baut entwirft ein E-Commerce-Lernsystem auf der Grundlage der Theorie des erfahrungsbasierten Lernens nach Kolb.

Schlüsselwörter: Augmented Reality (AR), Kolb, erfahrungsbasiertes Lernen, Zyklus, E-Commerce 


\section{Introduction}

3D virtual worlds have impacted higher education in teaching and learning for many years. There has been a growing demand for empirical research to inform instructional design in 3D virtual learning environments. Augmented reality (AR) generates a synthetic environment through computer graphics that supplements the learner's perception of the real world. Therefore, the AR application allows for the simulation, visualization, addition of information, and interaction with the virtual objects without being totally immersed in the virtual environment.

A learning situation takes into consideration how the environment may impact the learner and calls for an interaction between the learner and his or her environment (Dewey, 1916). Dewey believed that learning, for students, should be real and applicable to daily living (Dewey, 1916). Therefore, knowledge is based on active experiences of learners; education should be experimental and experiential. As a result, experiential learning theory is based upon the work of Dewey, Lewin, and Piaget (Kolb, Boyatzis, \& Mainemlis, 2002).

Piaget's instructional theories focus on real-life activities as a method of motivating learners (Kolb, Boyatzis, \& Mainemlis, 2002). In short, the real life learning context is an important factor that may affect the learners' performance, while also potentially enhancing their learning interest. The learners actively interact with the real world by using their knowledge from daily life, thus increasing the effectiveness of learning outcomes (Chen \& Tsai, 2012). There are three benefits of computer-based simulation technology to real life activities and learning:

(1) computer-based learning environments allow for the physical integration of different authentic media, (2) make adaptive interactive trainings more possible than other types of media, and (3) facilitate the simulation of realistic complex relations between different objects within a learning environment. (Horz, Winter, \& Fries, 2009, p.818)

A learning strategy that implements learning through action, doing and experience approach is experiential learning (Kolb, 1984). Many educators and researchers apply virtual reality or augmented reality into experiential learning instructions (Jarmon et al., 2009; Wojciechowski \& Cellary, 2013). For example, Wojciechowski and Cellary (2013) found that an augmented reality environment enabled teachers to carry out a chemical experiment following the experiential learning theory, which they might not have otherwise been able to conduct.

\section{A review of experiential learning theory}

Kolb et al. (2002) proposed that experiential learning allows learners to build their knowledge and skills through a four-stage learning cycle: concrete experience (CE), reflective observation (RO), abstract conceptualization (AC), and active experimentation (AE) (Kolb et al., 2002; McLeod, 2013). The learners accumulate their knowledge based upon the learning cycle due to the recursive process of experiencing, reflecting, thinking, and acting in the learning situation. The process provides feedback, and then encourages new action and evaluation of the consequences of that action. The four stage learning cycles are discussed as follows (Kolb et al., 2002; McLeod, 2013).

(1) Concrete Experience. This stage of the learning cycle emphasizes how a learner experiences an everyday situation. The learner typically will encounter the situation in a new way.

(2) Reflective Observation. Learners understand, conclude and think about the experience, and 
then transform that experience into additional knowledge. In this stage, the learner reflects on what they did and observed, wrapping up with a discussion on what they gained from the experience.

(3) Abstract Conceptualization. In this learning stage, learners integrate theories and concepts into the learning process with their critical thinking. Thus, the learner is trying to conceptualize a theory or model connected with what is observed.

(4) Active Experimentation. Learners actively engage in a practical approach and are concerned with real life activities to test their developed theory. In this stage, learners plan on how to improve and test a theory or model based upon the previous stages of the learning cycle.

\section{Integrating AR technology and experiential learning theory}

Carmigniani et al. (2011) defined augmented reality as "a real-time direct or indirect view of a physical real world environment that has been enhanced/augmented by adding virtual computer generated information to it" (p.342). Augmented reality technology integrates 3D virtual objects generated by computer imagery into the learner's immediate surroundings and into any indirect view of the real world environment (Cuendet et al., 2013; Park, 2011). 3D computer generated graphics can be spatially overlaid on 3D objects and real imagery (usually captured by video cameras) to create visual AR. For augmented reality, most images are real and can interact with the virtual world in real-time. El Sayed et al. (2011) noted that recent AR applications are designed to offer a useful, effective, and interactive tool for instruction.

AR techology offers learners the opportunity to interact with 3D virtual objects integrated within a real world environment. Thus, learners can explore or navigate an AR learning environment and manipulate the 3D learning objects using a mouse or a physical marker card. Wiley(2001) proposed connecting the learning behaviors with AR technology in a virtual 3D learning system for learners. Learners operate their virtual characters to move around the environment, examine 3D objects, or to learn about presented content (e.g., textual or audiovisual elements). In addition, learners can also actively engage with the learning environment, observing or interacting with any of the 3D learning model content. As a result, AR technology meets the requirements for experiential learning, since Roussou (2004) noted that interactivity is a key determinant of the effectiveness for experiential learning.

AR applications offer intuitive interaction, a sense of physical imagination, and a feeling of immersion for learners. Immersion allows learning to be situated in a comprehensive and realistic experience. This immersion feature of AR provides the opportunity to support situated learning; learning is immersed in the context in which it will be applied (Lave \& Wenger, 1991). Kolb (1984) noted that learners must act; Kolb's experiential learning cycle concept applies to the 3D immersive virtual worlds, which allow learners to learn by doing, to observe the outcomes of their actions, to test their hypotheses about the world, and to reflect further on their own understanding of the experiential learning cycle concept (Chee, 2007; Hew \& Cheung, 2010).

\section{A case study of augmented reality learning system}

AR technology can reduce the level of complexity of presented concepts, so the learners are more easily able to gain knowledge and to understand the material at hand. Therefore, AR technology is a useful tool to create experiential learning environments for learners. This study builds an E-commerce learning system based upon experiential learning theory for learners. The author created E- 
commerce learning environments, enabling experiential learning, through an image-based augmented reality and a virtual reality. The 3D shopping mall learning system was designed by integrating Unity 3.0 and 3D graphic modules of the system, drawn and rendered with 3DsMax and Maya. Additionally, D'Fusion studio was applied to further create an augmented reality experiential learning application.

The system uses the AR technology, comprised of a video camera, a display device, and 'real objects' represented by a set of card markers. The main page of the E-commerce learning system is shown in Figure 1. The learners can explore and navigate E-commerce related knowledge in the 3D shopping mall learning environment as shown in Figure 2. Thus, the learner is experiencing a shopping mall activity to gain concrete experience. After the learner understands the concept of e-commerce, the learner could rely on their understanding and careful judgment of the system. Hence, the system provides online testing for learners to do reflective observation as shown in Figure 3.

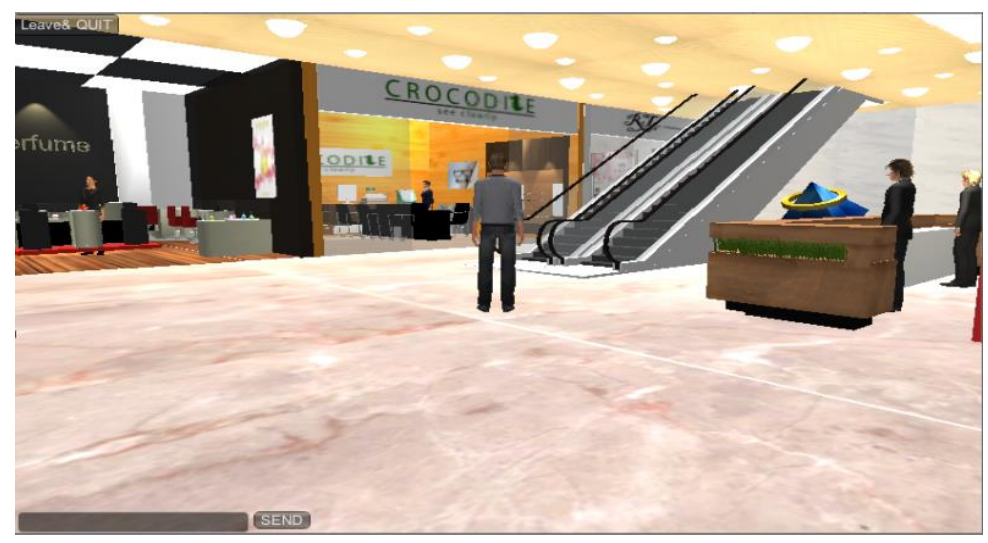

Figure 1: The main page of the E-commerce learning system

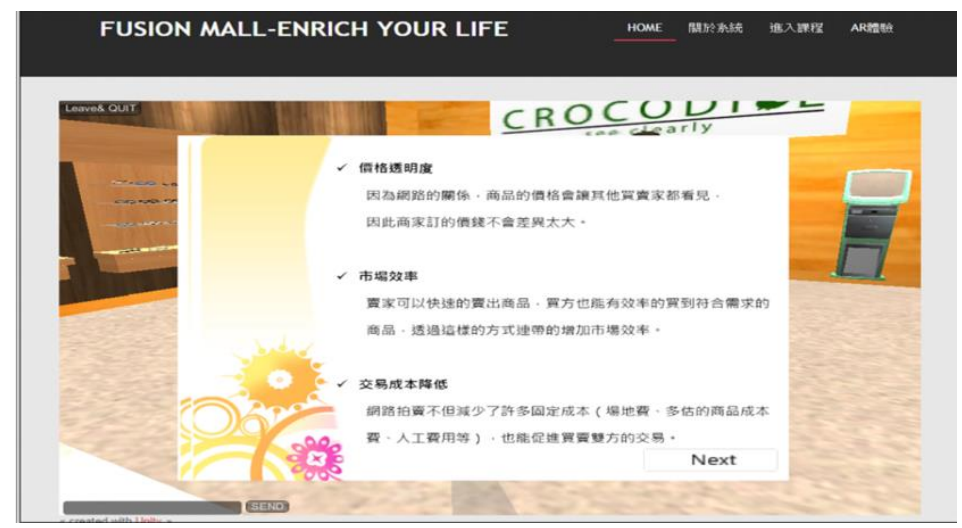

Figure 2: A screenshot for the course content 


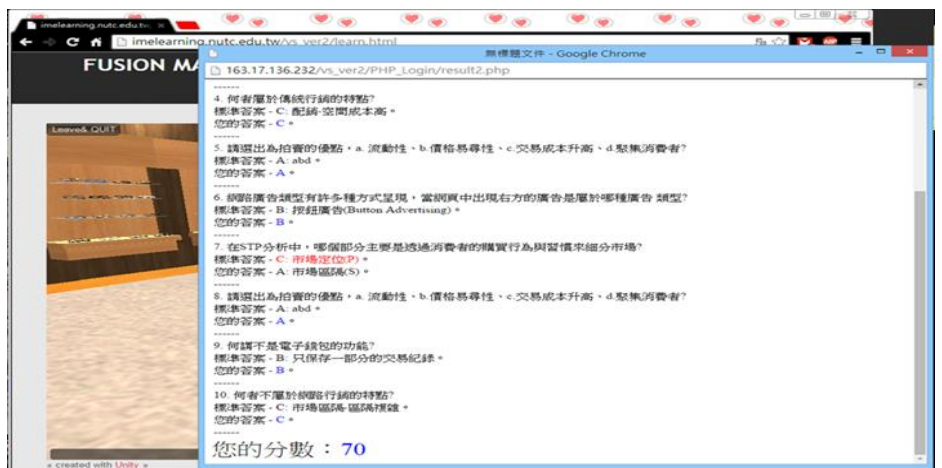

Figure 3: A screenshot for an online test.

The learner navigates through an online AR shopping learning scenario as shown in Figure 4. For more realistic learning, the learner wears a bracelet with a square-shaped marker on their wrist (in Figure 5), allowing the AR Browser to combine with the 3D virtual watch and superimpose it onto the learner's wrist. This provides live video images captured by a video camera as shown in Figure 6. Moreover, the learner is able to try out the different 3D virtual watches with the same processes as how we buy a watch in reality. In this learning stage, the learner makes links about the previous learning experience of e-commerce and any theories or knowledge that they can apply, such as experiential marketing. Finally, the learner would take a practical approach in concluding the online through shopping procedures (in Figure 7).

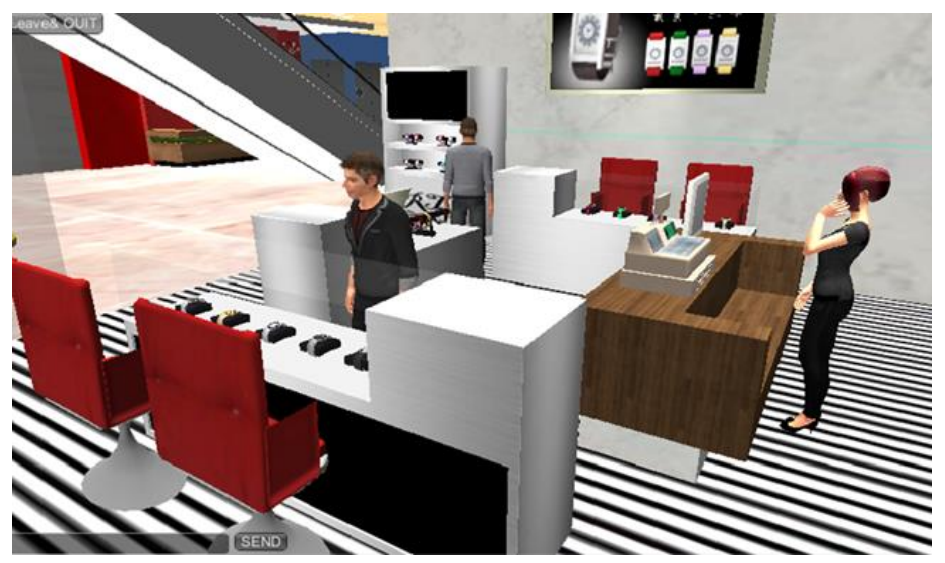

Figure 4. AR online shopping learning scenario.

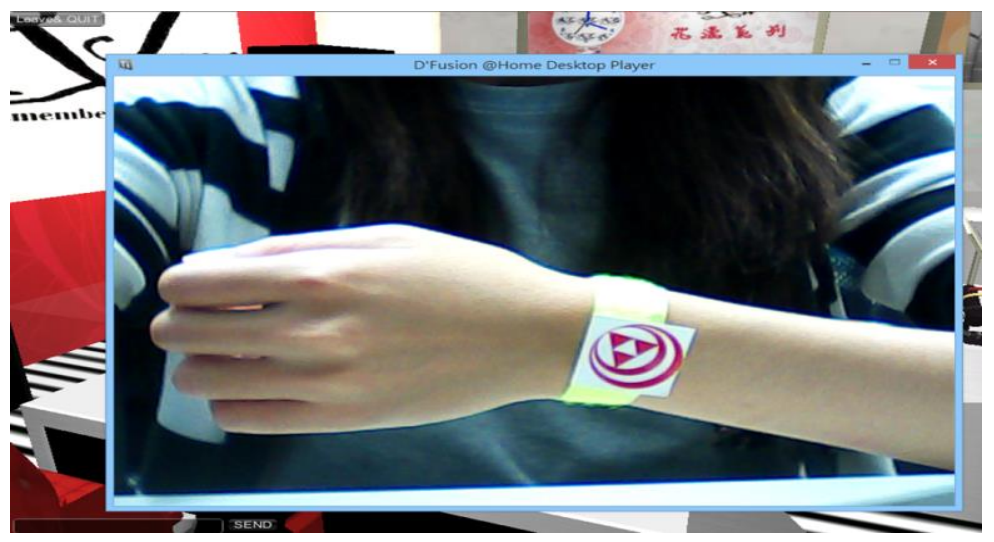

Figure 5. The learner wears a bracelet with a square-shaped marker on her wrist. 


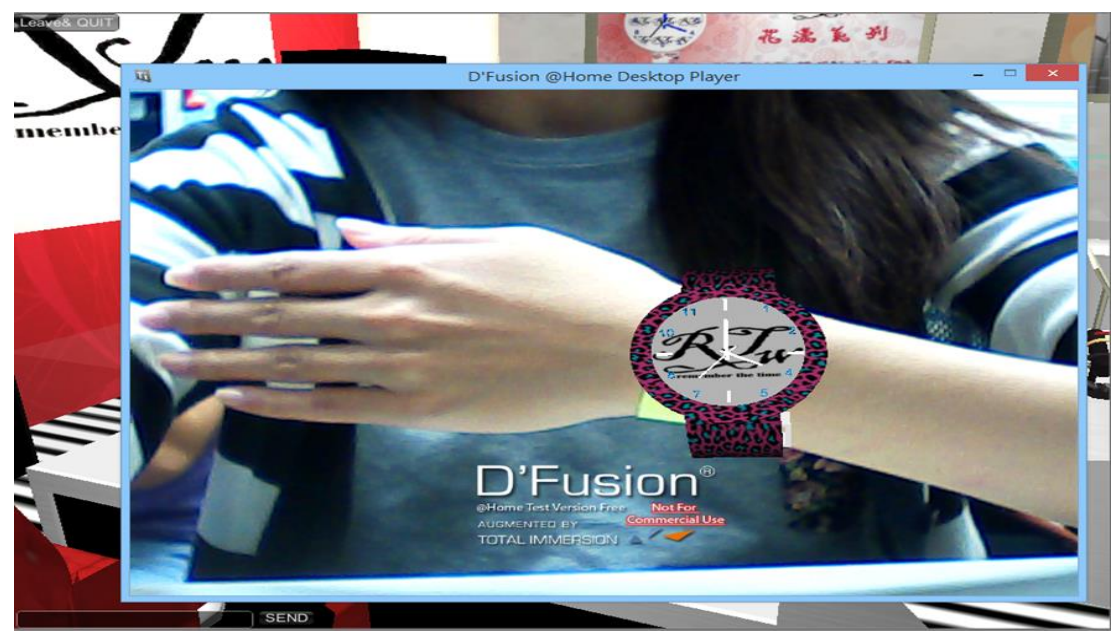

Figure 6. The learner tries out the 3D virtual watch.

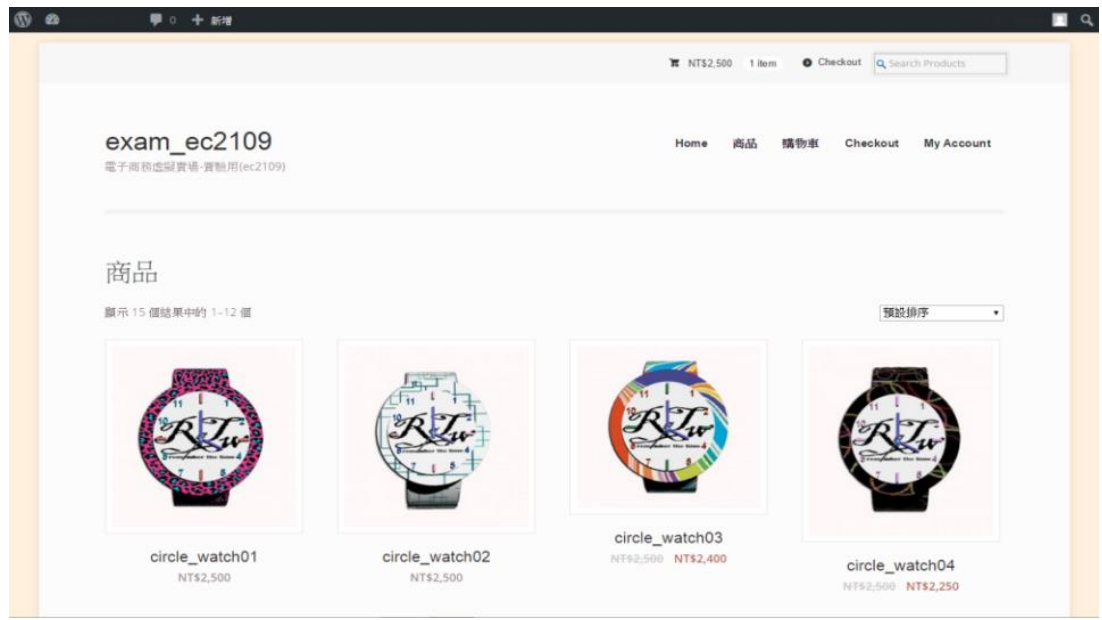

Figure 7. Online shopping procedures.

\section{Conclusion}

The study demonstrates a case study of applying augmented reality technology into e-commerce instructions, based upon experiential learning theory. In particular, learners were able to learn by doing; they applied previously learned online shopping concepts into their daily life. The author describes the interactions among the augmented reality, as shown in above figures, to affirm the importance of experiential activities learning. Interaction with a simulated environment through the augmented reality learning can be a reasonable and viable substitute for the real-world experience. The more the technology is used with the appropriate instructional theories, such as in this study, the less design efforts will cost. From the results of the case study, the connections between the experiential learning cycle and an e-commerce course design are shown in Figure 8. However, this study needs additional empirical investigation to evaluate learners' perceptions in this system in the future. 


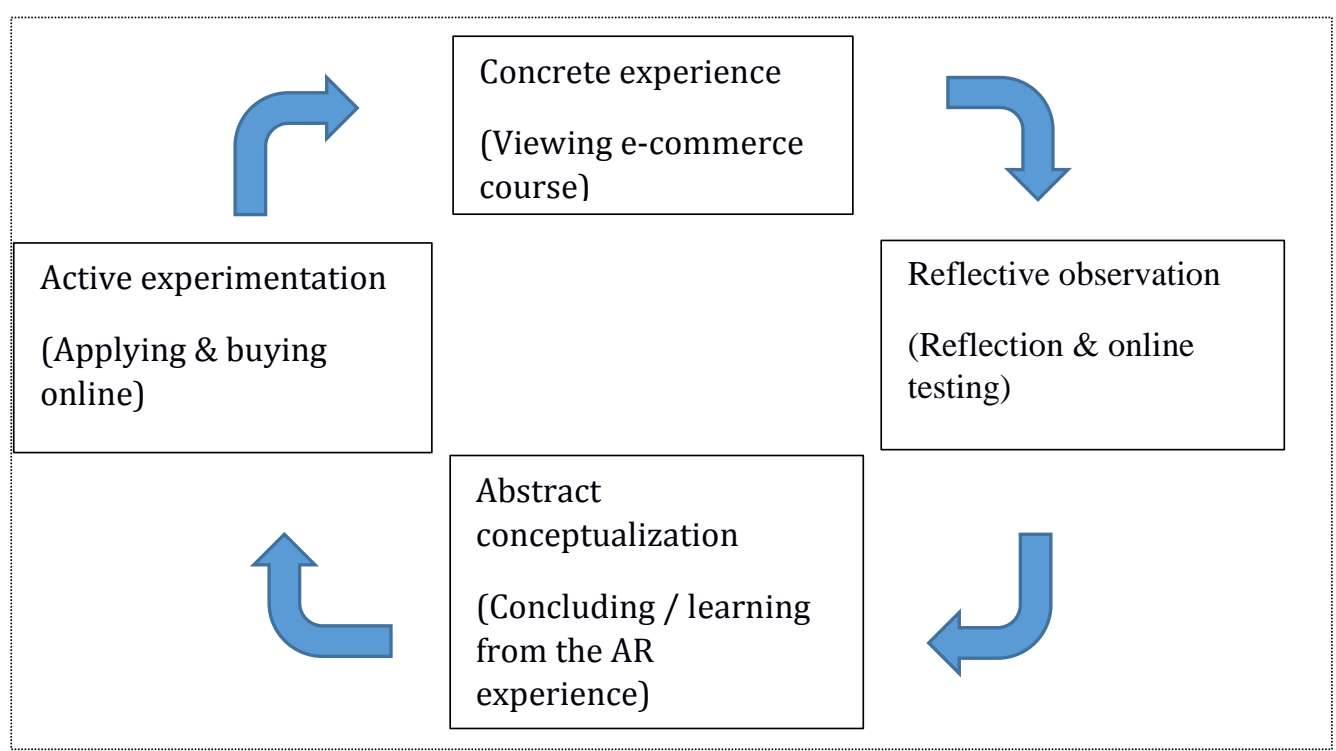

Figure 8: Experiential learning model for E-commerce instructions.

\section{Acknowledgement}

This research was supported by the National Science Council of Taiwan under contract numbers NSC100-2511-S-025-003-MY3.

\section{References}

Carmigniani, J.; Furht, B.; Anisetti, M.; Ceravolo,P.; Damiani, E. \& Ivkovic, M. (2011): Augmented reality technologies, systems and applications. In: Multimed Tools Appl, 51, pp. 341-377.

Chee, Y. S. (2007): Embodiment, embeddedness, and experience: game-based learning and the construction of identity. In: Research and Practice in Technology Enhanced Learning, 2, 1, pp. 3-30.

Chen, C.-M. \& Tsai, Y.-N. (2012): Interactive augmented reality system for enhancing library instruction in elementary schools. In: Computers \& Education ,59, pp. 638-652.

Cuendet,S., Bonnard, Q., Do-Lenh,S. \& Dillenbourg, P.(2013): Designing augmented reality for the classroom. In: Computers \& Education, 68, pp. 557-569.

Dewey, J. (1916): Democracy and education. New York: The Free Press .

El Sayed, N.A. M., Zayed, H. H., Sharawy , M. I.(2011): ARSC: Augmented reality student card: An augmented reality solution for the education field. In: Computers \& Education ,56, pp. 1045-1061.

Kolb, D. A. (1984): Experiential learning: experience as the source of learning and development. Englewood Cliffs, NJ: Prentice-Hall.

Kolb, D.A., Boyatzis, R.E. \& Mainemelis, R.E. (2002): Experiential Learning Theory: Previous Research and New Directions. In: R. J. Sternberg and L. F. Zhang (Eds.): Perspectives on cognitive, learning, and thinking styles. NJ: Lawrence Erlbaum, 2000.

Hew, K. F. \& Cheung, W. S. (2010): Use of three-dimensional (3-D) immersive virtual worlds in K-12 and higher education settings: A review of the research. In: British Journal of Educational Technology, 41 (1), pp. 33-55.

Horz, H., Winter, C. \& Fries, S. (2009): Differential benefits of situated instructional prompts. In: Computers in Human Behavior, 25, pp. 818-828.

Jarmon et al. (2009): Virtual world teaching, experiential learning, and assessment: An interdisciplinary communication course in Second Life. In: Computers \& Education, 53, pp. 169-182. 
Lave, J. \& Wenger, E. (1991): Situated learning: Legitimate peripheral participation. NY: Cambridge University Press.

McLeod, S. (2013): Kolb-Learning Styles, Simply Psychology. Retrieved from http://www.simplypsychology.org/learning-kolb.html

Park, J.S. (2011): AR-Room: a rapid prototyping framework for augmented reality applications. In: Multimedia Tools Application, 55, pp. 725-746.

Roussou, M. (2004): Learning by doing and learning through play: an exploration of interactivity in virtual environments for children. In: ACM Computers in Entertainment, 2(1), pp. 1-23. NY: ACM Pres.

Wiley, D. A. (2001): Connecting learning objects to instructional design theory. A definition, a metaphor and a taxonomy. In: The Instructional Use of Learning Objects. AIT/AECT, Bloomington, Ind, USA, pp. 3-29.

Wojciechowski, R. \& Cellary, W. (2013): Evaluation of learners' attitude toward learning in ARIES augmented reality environments. In: Computers \& Education, 68, pp. 570-585.

\section{About the Author}

Prof. Dr. Hsiu-Mei Huang: Department of Information Management, National Taichung University of Science and Technology (Taiwan). Contact: hmhuang@nutc.edu.tw 